\title{
3. HIGH-RESOLUTION MAGNETIC SURVEYS OVER THE MIDDLE VALLEY MOUNDS, NORTHERN JUAN DE FUCA RIDGE ${ }^{1}$
}

\author{
Maurice A. Tivey ${ }^{2}$
}

\begin{abstract}
High-resolution, near-bottom magnetic surveys were carried out over two hydrothermal mound sites in Middle Valley, a thickly sedimented ( 0.2 to $1.5 \mathrm{~km}$ thick) abandoned spreading center, $20 \mathrm{~km}$ east of the current spreading axis of the northern Juan de Fuca Ridge. Ocean Drilling Program Leg 139 drilled both the relict Bent Hill mound area (Site 856, $48^{\circ} 26^{\prime} \mathrm{N} 128^{\circ} 41^{\prime} \mathrm{W}$ ) and the hydrothermally active Dead Dog vent field (Site $858,48^{\circ} 27^{\prime} \mathrm{N} 128^{\circ} 43^{\prime} \mathrm{W}$ ). No magnetic anomalies were found over the active Dead Dog hydrothermal area, but a large-amplitude $(6000 \mathrm{nT})$, short-wavelength $(<200 \mathrm{~m})$ positive magnetic anomaly was measured over the massive sulfide mound south of the Bent Hill mound. No anomalies were found over the Bent Hill mound itself. A magnetic anomaly was also found over the active $264^{\circ} \mathrm{C}$ vent site $300 \mathrm{~m}$ south of Bent Hill. Drilling at the sulfide mound revealed sulfide and magnetite mineralization to at least $95 \mathrm{~m}$ depth with at least $60 \mathrm{~m}$ horizontal extent. The shape and limited extent of the magnetic anomaly is consistent with a positively magnetized, three-dimensional body at depth. The magnetic anomaly can be modelled by a buried sphere centered at $60 \mathrm{~m}$ below seafloor with a radius of $60 \mathrm{~m}$, or a long rod buried at $30 \mathrm{~m}$ below seafloor. A more realistic pipelike body of radius $60 \mathrm{~m}$ and magnetization $14 \mathrm{~A} / \mathrm{m}$ predicts that the mineralized zone extends to $180 \mathrm{~m}$ in depth. In all cases, the magnetic field predicts continued magnetic mineralization at depth. Although basaltic sills were intersected in a number of the drillholes, no magnetic anomalies were associated with them. The lack of anomalies in the Dead Dog area suggests that no buried bodies of magnetic material equivalent to those found in the Bent Hill area exist at depth.
\end{abstract}

\section{INTRODUCTION}

The primary purpose of the Middle Valley near-bottom magnetic surveys was to determine the presence and extent of buried magnetic bodies that may not be visible at the seafloor using conventional deeptow camera systems and acoustic sidescan surveys. Magnetic surveys offer a rapid and efficient method of investigating the subsurface by allowing a determination of the depth and areal extent of source bodies in a quantitative manner (Tivey and Johnson, 1989; Tivey et al., 1993). The Middle Valley hydrothermal mounds area offered a good opportunity to test the near-bottom magnetic survey method for a number of reasons.

1. Middle Valley is thickly sedimented with generally nonmagnetic sediments. The basement is buried deep enough $(>500 \mathrm{~m})$ to be unimportant for the wavelength of the anomalies being surveyed $(<500 \mathrm{~m})$.

2. The thick sediment cover in Middle Valley also provides a thermally insulating blanket that results in estimated basement temperatures of approximately $300^{\circ} \mathrm{C}$ (Davis and Villinger, 1992). These high temperatures exceed the Curie temperature for typical titanomagnetite minerals $\left(150-300^{\circ} \mathrm{C}\right)$ found in young oceanic basalt (Irving, 1970; Johnson and Atwater, 1977), which could result in thermally demagnetized basement rocks (Levi and Riddihough, 1986). The sediment cover also enhances hydrothermal alteration and leaching of magnetic minerals, which appears to be the dominant process in the demagnetization of the basement rocks of Middle Valley based on studies of extrusives recovered at Hole 857 (Fukuma et al., this volume). The well-developed, sea-surface magnetic anomaly low located over Middle Valley within the positive central Brunhes anomaly supports the hypothesis of nonmagnetic basement (Currie and Davis, this volume).

3. A 1987 regional piston coring program in Middle Valley (Franklin et al., 1987; Goodfellow et al., 1987) recovered massive sulfides that contain large amounts of magnetic pyrrhotite (Davis et

\footnotetext{
'Mottl, M.J., Davis, E.E., Fisher, A.T., and Slack, J.F. (Eds.), 1994. Proc. ODP, Sci. Results, 139: College Station, TX (Ocean Drilling Program).

${ }^{2}$ Dept. of Geology and Geophysics, Woods Hole Oceanographic Institution, Woods Hole, MA 02543, U.S.A.
}

al., 1987). The presence of magnetic sulfides suggested that magnetic surveys may prove useful in locating and delineating such pyrrhotiterich sulfide ore bodies at depth.

4. Finally, the Ocean Drilling Program (ODP) Leg 139 drilling program in Middle Valley provides the unique opportunity to assess the predictions of the magnetic method with direct sampling in the vertical dimension.

\section{MAGNETIC SURVEY METHODS}

Near-bottom magnetic surveys over the hydrothermal mounds of Middle Valley were carried out in 1988 using the University of Washington Deep Towed Magnetometer (DTM) system and in 1990 using the $A L V I N$ submersible magnetometer system. Both magnetometers utilize three-component fluxgate sensors adapted for deepocean depths. The DTM system is a self-recording magnetometer towed on a nonmagnetic umbilical cable behind a depressor weight that is attached to a standard deep sea trawl cable. The DTM system measures magnetic field data along with depth, heading, and altitude. The ALVIN magnetometer was mounted at the front of the submersible in the forwardmost part of a nonmagnetic basket. The induced field effects of the submersible were evaluated by spinning the submersible in the water column on descent and ascent. A correction for the heading effect of the submersible is obtained by using a NelderMeade approach to minimize the variations in total magnetic field with heading by adjusting the offsets and calibration factors of the three orthogonal field components measured by the fluxgate sensors (Press et al., 1986). Fluxgate sensor drift is not a problem with these deep-tow surveys due to the short duration of the surveys (a few hours) and the relatively constant temperature environment of the deep ocean, temperature being the main culprit in sensor drift. The deep-tow and submersible survey platforms generally operate at two different survey altitudes, with deep-tow measurements made at 100 $\mathrm{m}$ altitude or greater and submersible measurements made closer to the seafloor at $10 \mathrm{~m}$ altitude or less. These two different levels of survey allow useful constraints to be placed on the extent and geometry of a source body. The 1988 DTM survey was conducted from the research vessel CSS Tully during the Geological Survey of Canada (GSC) cruise (TUL-8804) to Middle Valley. The DTM towfish was 


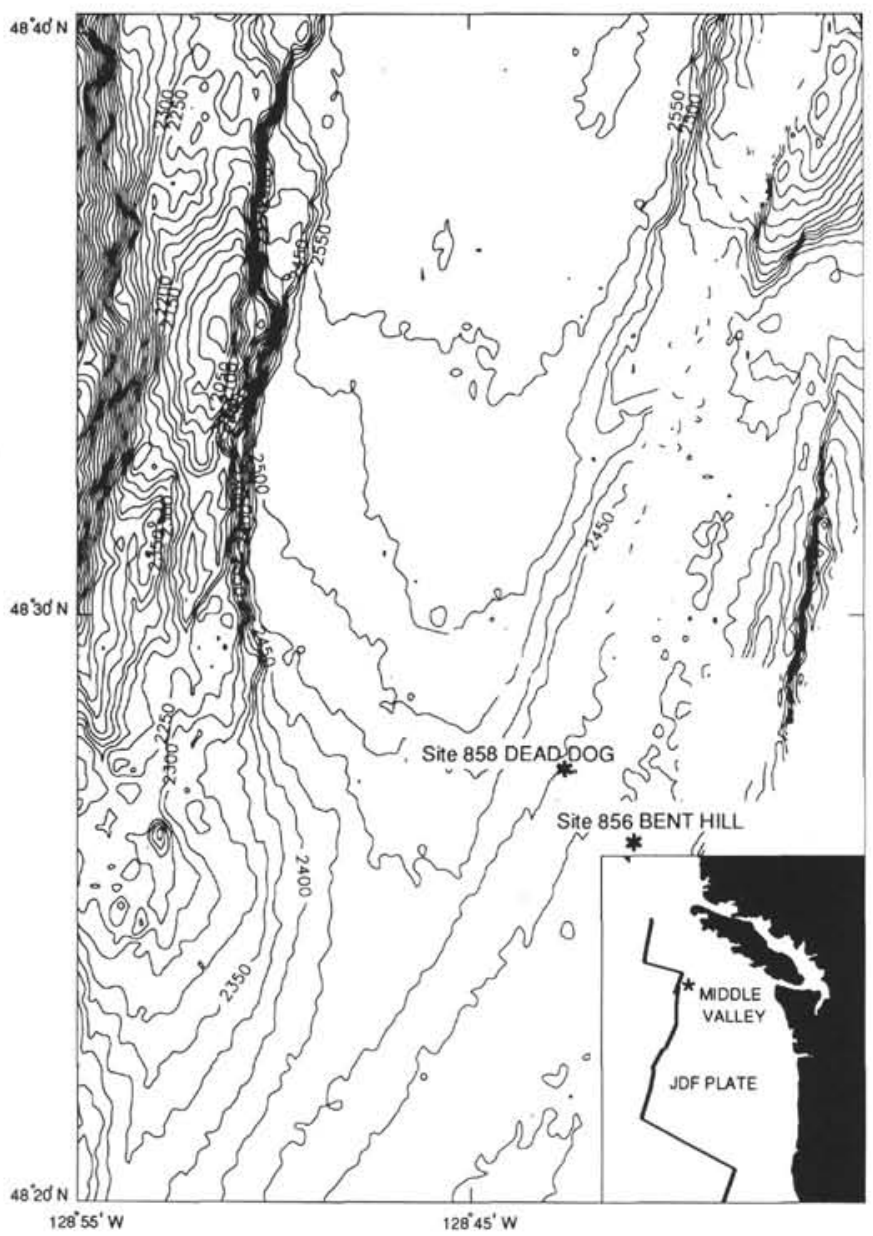

Figure 1. Sea Beam bathymetry map showing the location of ODP sites at the Dead Dog and Bent Hill hydrothermal mound areas in Middle Valley on the northern Juan de Fuca (JDF) Ridge.

transponder navigated within an acoustic transponder net that provided positional errors of approximately 5 to $10 \mathrm{~m}$ accuracy within the net. The 1990 ALVIN magnetic surveys were part of a GSC/United States Science Advisory Committee (USSAC) site survey dive program (ALVIN Dives 2251-2255). Useful magnetic data were collected on two of the five dives (Dives 2253 and 2254). Navigation was again provided by an acoustic transponder net.

Total magnetic field data from both the 1988 and 1990 surveys were calculated from the vector sum of the three-component data. The magnetic data were collected at sample rates of $1 \mathrm{~Hz}$ for the ALVIN magnetic survey and $0.3 \mathrm{~Hz}$ for the DTM survey and merged with the transponder navigation data using linear interpolation between handedited navigational fixes. Although the transponder fixes were referenced to geographic coordinates, navigational shifts between the 1988 and 1990 data sets and the ODP coordinates are required due to differences in the geoid specifications used in the 1988 and 1990 surveys. A navigational shift was calculated by matching bathymetric information from the deep-tow surveys (1988) and the ALVIN survey (1990) with the Global Positioning Satellite (GPS) coordinates of known features on the seafloor. The 1988 data were shifted by $81 \mathrm{~m}$ west and $58 \mathrm{~m}$ north and the 1990 data were shifted by $69 \mathrm{~m}$ east, $269 \mathrm{~m}$ north to fit the ODP GPS site coordinates.

\section{MAGNETIC SURVEY RESULTS}

The near-bottom magnetic surveys focused on two hydrothermal mound areas previously identified in Middle Valley: Bent Hill (ODP

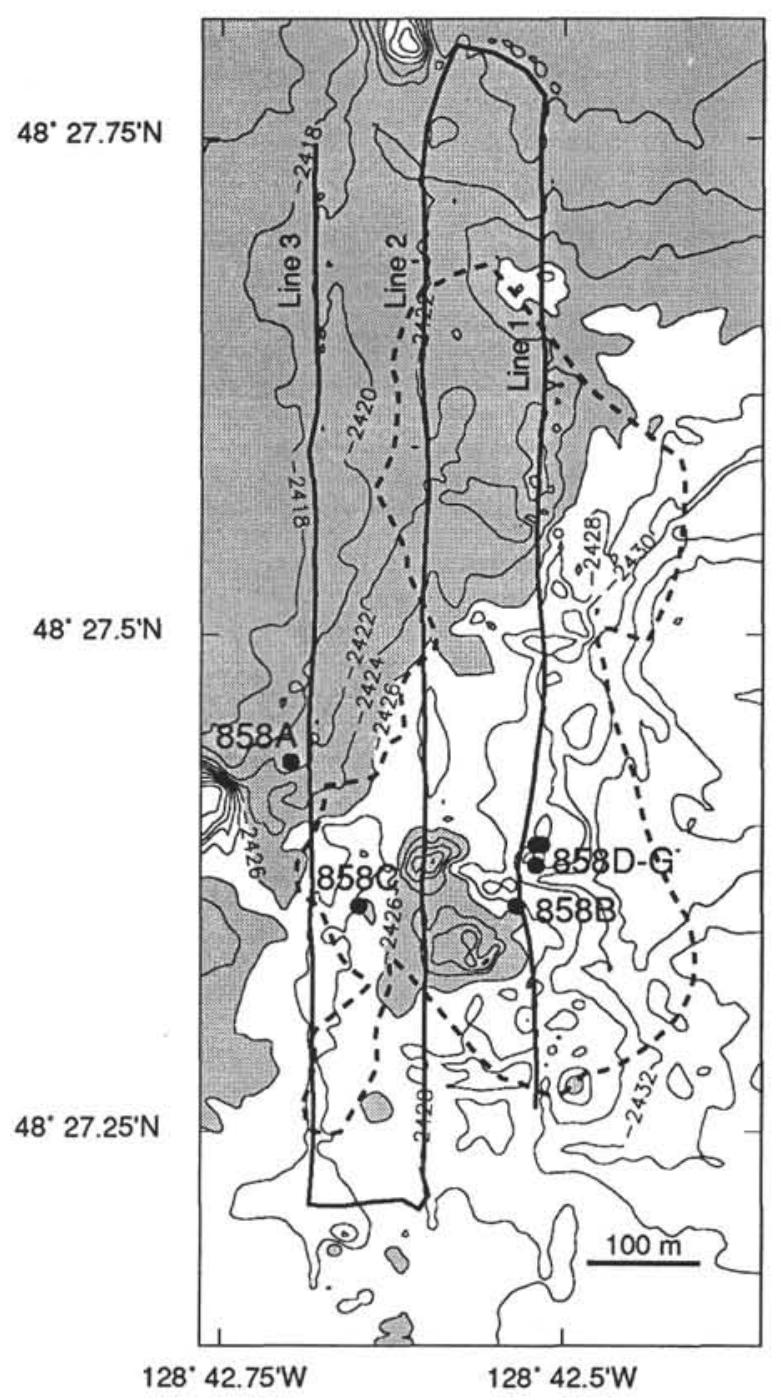

Figure 2. Bathymetric map of the Dead Dog area (Site 858) compiled from the ALVIN Mesotech survey (Dive 2254) and ALVIN altimeter data. The contour interval is $2 \mathrm{~m}$ and bathymetry shallower than $2426 \mathrm{~m}$ is shaded. The tracklines of the magnetic profiles (see Figure 4 for line 2 profile) are shown by the solid black line. The outline of the acoustic reflector determined from sidescan (see Shipboard Scientific Party, 1992; Davis and Villinger, 1992) is shown by the dashed line.

Site $856,48^{\circ} 26^{\prime} \mathrm{N}, 128^{\circ} 41^{\prime} \mathrm{W}$ ) and Dead Dog vent field (ODP Site $858,48^{\circ} 27^{\prime} \mathrm{N}, 128^{\circ} 43^{\prime} \mathrm{W}$ ) (see Fig. 1). The Dead Dog vent field contains a number of small mounds ( 5 to $15 \mathrm{~m}$ high, 25 to $35 \mathrm{~m}$ diameter), which have active high-temperature hydrothermal vents located at the mound summits (Shipboard Scientific Party, 1992). The mounds sit in a broad regional topographic low of turbidite sediments on an up-faulted block that gently dips to the southeast (Fig. 2). The Bent Hill area consists of a large, $35 \mathrm{~m}$ high, $400 \mathrm{~m}$ diameter mound with smaller ( $<50 \mathrm{~m}$ diameter) satellite mounds to the south (Fig. 3). The entire Bent Hill region resides in a flat turbidite plain with an acoustic basement at a depth of approximately 350 to $450 \mathrm{~m}$ (Shipboard Scientific Party, 1992). A small mound located $100 \mathrm{~m}$ south of the main Bent Hill mound (hereafter referred to as the Sulfide mound) was found to be associated with a significant amount of pyrrhotiterich, massive sulfide through submersible, deep-tow camera, and piston core surveys (Franklin et al., 1987) (Fig. 3). Unlike the Dead Dog area, the mounds in the Bent Hill area appear to be mostly relict with no current hydrothermal activity at the main Bent Hill mound or adja- 


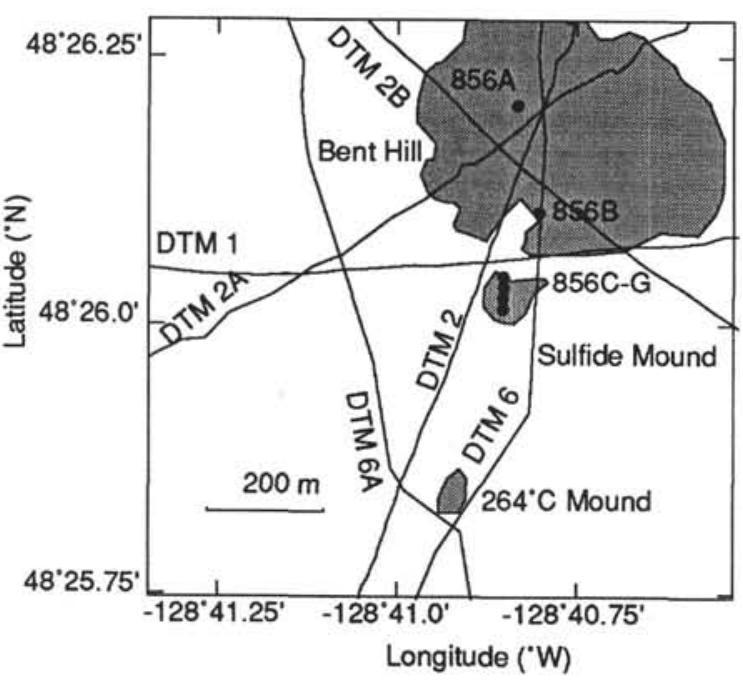

Figure 3. Map of the Bent Hill area showing the deep-tow magnetometer tracklines collected in 1988. The main Bent Hill mound and Sulfide mound are shaded gray with drillhole locations as indicated. The magnetic field data along these profiles is shown in Figure 5.

cent Sulfide mound. Hydrothermal activity does occur $300 \mathrm{~m}$ south of the main Bent Hill mound, however, where a small mound $(<50 \mathrm{~m}$ in diameter) is venting at temperatures of $264^{\circ} \mathrm{C}$ (Shipboard Scientific Party, 1992). The pyrrhotite-rich massive sulfide material recovered at this site is similar to samples taken at the Sulfide mound ( $R$. Zierenberg, pers. comm., 1992).

\section{Dead Dog Magnetic Survey}

A regional magnetic and bathymetry survey of the Dead Dog vent field (Site 858) was carried out during ALVIN Dive 2254 (Fig. 2) at a constant depth of $2400 \mathrm{~m}$. Bathymetry was measured using the ALVIN Mesotech scanning sonar $\left(114^{\circ}\right.$ total scan angle, maximum range $75 \mathrm{~m}$ ), which results in high-resolution swath bathymetry coverage in a zigzag, across-track pattern (data provided by Dr. H. Paul Johnson, University of Washington). Unfortunately, the lack of attitude sensors on the ALVIN (pitch, yaw, and roll) means that an arbitrary assumption concerning the roll angle ( $6^{\circ}$ to starboard) of the submersible is necessary to remove a sloping topography artifact. Nevertheless, the resultant topography, shown in Figure 2, is consistent with the sidescan data and other geological observations of the Dead Dog mound area.

The measured total magnetic field data observed along Line 2 (see Fig. 2 for location) and shown in Figure 4 is typical of the magnetic data over this region. Line 2254-2 passed directly over the main Dead Dog mound site at an altitude of $25 \mathrm{~m}$ and shows no evidence of any magnetic anomalies (Fig. 4). In fact, no magnetic anomalies are observed over any portion of the Dead Dog vent field. This lack of magnetic anomalies is entirely consistent with the drilling results obtained at the Dead Dog vent field drill site. Six shallow drillholes were drilled at Site 858 during ODP Leg 139; Hole 858A is located outside the Dead Dog hydrothermal field and the other five holes are sited within the Dead Dog hydrothermal field (Holes 858B-858G). Hole 858 A encountered primarily hemipelagic sediments with typically low natural remanent magnetization (NRM) of less than $0.1 \mathrm{~A} / \mathrm{m}$ (Shipboard Scientific Party, 1992). The Dead Dog vent field drillholes encountered hydrothermally altered sediments and a small amount of sulfides. Holes $858 \mathrm{~F}$ and $858 \mathrm{G}$ intersected fine-grained basaltic sills at depths of 249 and $277 \mathrm{~m}$ below seafloor (mbsf), respectively (Shipboard Scientific Party, 1992). The paleomagnetic measurements of this basalt show a very low NRM $(<1 \mathrm{~A} / \mathrm{m})$ and low stability compared with paleomagnetic measurements of typical basalts of the Juan de
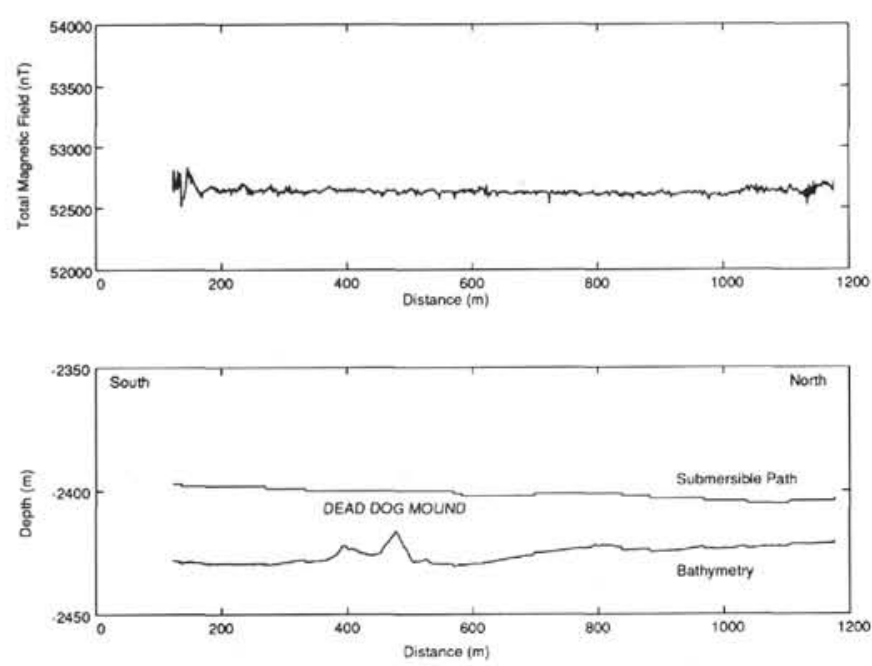

Figure 4. Magnetic profile 2254-2 showing the bathymetry and ALVIN submersible path in the lower box and the observed magnetic field in the upper box. The location of this profile is shown in Figure 2. Note the absence of any magnetic anomaly over the active hydrothermal Dead Dog mound.

Fuca region (Johnson and Holmes, 1989). Since a magnetic anomaly only occurs at the edges of a magnetized body, anomalies will not necessarily be associated directly with the location of the drillhole intersection of a basaltic unit. Nevertheless, there are no obvious edgelike magnetic anomalies seen in any of the magnetic data in the Dead Dog mound survey. The low NRM of the basalt and the lack of any significant sulfide deposits at depth in the Dead Dog mound area explains the absence of any magnetic anomalies at this site.

\section{Bent Hill Magnetic Survey}

In contrast to the Dead Dog hydrothermal mound àrea, a significant near-bottom magnetic anomaly was discovered in the Bent Hill area (Site 856). Near-bottom magnetic data were collected over the Bent Hill region using both deep-tow (in 1988) and submersible (in 1990) sensors. The deep-tow magnetic data show a distinctive shortwavelength magnetic anomaly high over the Sulfide mound just to the south of Bent Hill mound, but no anomalies associated with the main Bent Hill mound itself. Three separate deep-tow profiles cross the Sulfide mound at slightly different locations and altitudes and show various aspects of the magnetic anomaly over this feature (see Fig. 3). DTM88-1, an east-west profile, crosses slightly north of the Sulfide mound at an altitude of $150 \mathrm{~m}$ and measures an approximately $500-\mathrm{m}$ wavelength, 300-nT magnetic anomaly, (Fig. 5A). DTM88-2, an approximately north-south profile, crosses slightly to the west of the Sulfide mound and shows an approximately $200-\mathrm{m}$ wavelength, 1250-nT magnetic anomaly at an altitude of $25 \mathrm{~m}$ (Fig. 5B). Finally, profile DTM88-6, a north-south profile slightly east of the Sulfide mound, measures an approximately $190-\mathrm{m}$ wavelength, 600-nT magnetic anomaly at an altitude of $50 \mathrm{~m}$ (Fig. 5C). The consistent appearance of this magnetic anomaly suggests that a highly magnetized body resides beneath the Sulfide mound.

A more detailed magnetic survey was carried out at Bent Hill using the submersible ALVIN (Dive 2253), which measured a 6000-nT magnetic anomaly high over the Sulfide mound (at an altitude of $<5 \mathrm{~m}$ ) just south of the main Bent Hill mound (profile A2253; Figs. 6 and 7). Another, smaller magnetic anomaly also appears to be present at the beginning of the dive, at the location of the active $264^{\circ} \mathrm{C}$ vent site (Fig. 7). Although a complete profile over the actively venting mound is not available from this study, the presence of a magnetic anomaly does suggest a magnetized body at depth in the active vent area.

During Leg 139, Holes 856A and 856B (Fig. 3) penetrated the main Bent Hill mound and encountered mostly sediments and minor 
A
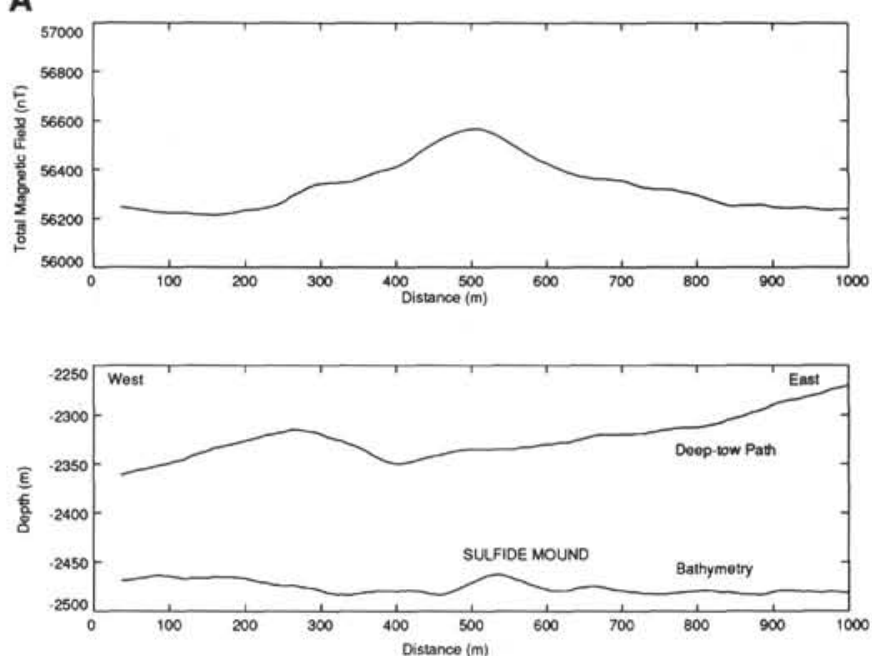

Figure 5. A. Magnetic profile DTM88-1 showing the bathymetry and deep-tow path in the lower box and the observed total magnetic field in the upper box. This east-west profile crosses slightly north of the Sulfide mound at an altitude of approximately $150 \mathrm{~m}$ and shows a $300 \mathrm{nT}$ magnetic anomaly with a wavelength of $500 \mathrm{~m}$. B. Magnetic profile DTM88-2 showing the bathymetry and deep-tow path in the lower box and the observed total magnetic field in the upper box. This north-south profile crosses slightly west of the Sulfide mound at an altitude of approximately $25 \mathrm{~m}$ and shows a strong $1250 \mathrm{nT}, 200$ $m$ wavelength magnetic anomaly. C. Magnetic profile DTM88-6 showing the bathymetry and deep-tow path in the lower box and the observed total magnetic field in the upper box. This north-south profile crosses slightly east of the Sulfide mound at an altitude of approximately $50 \mathrm{~m}$ and shows a distinct 600 $\mathrm{nT}, 190 \mathrm{~m}$ wavelength magnetic anomaly. The location of these profiles is shown in Figure 3.

sulfide talus. Basaltic sills were also intersected at depths of 62 and $120 \mathrm{mbsf}$ in Hole 858A and $114 \mathrm{mbsf}$ in Hole 858B. A series of drillholes $(856 \mathrm{C}-856 \mathrm{H})$ was also drilled across the Sulfide mound to the south of the Bent Hill mound (Fig. 3). These drillholes show that the massive sulfide deposit extends to at least $95 \mathrm{~m}$ depth and has a north-south extent of at least $60 \mathrm{~m}$ (Shipboard Scientific Party, 1992). The massive sulfides contain a large proportion of magnetic pyrrhotite, in addition to sphalerite, chalcopyrite, and pyrite (Goodfellow et al., 1987). Cores from Holes $856 \mathrm{G}$ and $856 \mathrm{H}$ show magnetite to be abundant at depth reaching $10 \%-25 \%$ by volume of the rock. Paleomagnetic measurements of the basaltic sill rocks from Holes $856 \mathrm{~A}$ and $856 \mathrm{~B}$ show relatively low NRMs $(3.5 \mathrm{~A} / \mathrm{m})$ compared with young basaltic rocks collected along other parts of the Juan de Fuca Ridge (Johnson and Holmes, 1989). In contrast, the NRM of a few massive sulfide samples from Hole $856 \mathrm{G}$ in the Sulfide mound is very high, reaching $340 \mathrm{~A} / \mathrm{m}$, but with low stabilities (i.e., a median destructive field $<30 \mathrm{mT}$ ) (Shipboard Scientific Party, 1992). Removal of the low-stability remanent component induced by drilling in Sample 139$856 \mathrm{G}-6 \mathrm{R}-3,126-128 \mathrm{~cm}$, suggests an NRM of approximately $14 \mathrm{~A} / \mathrm{m}$ compared with an initial NRM measurement of $337 \mathrm{~A} / \mathrm{m}$. These drilling results are consistent with the near-bottom magnetic field observations at Bent Hill. The weakly magnetized basaltic sills recovered in Holes $856 \mathrm{~A}$ and $856 \mathrm{~B}$ produce no observable magnetic anomaly edge effects near the Bent Hill mound. In contrast, the highly magnetic sulfides (pyrrhotite) and magnetite mineralization drilled at the Sulfide mound (Holes $856 \mathrm{C}-856 \mathrm{H}$ ) produce a large amplitude but localized magnetic anomaly high. The magnetite mineralization can account for between $5 \%$ and $20 \%$ of the rock and occurs as fine- to medium-grained octahedra; it is most likely a secondary product that forms from the seawater alteration of the massive pyrrhotite to pyrite (Shipboard Scientific Party, 1992). The magnetic field results also suggest that another magnetic sulfide deposit should be associated
B
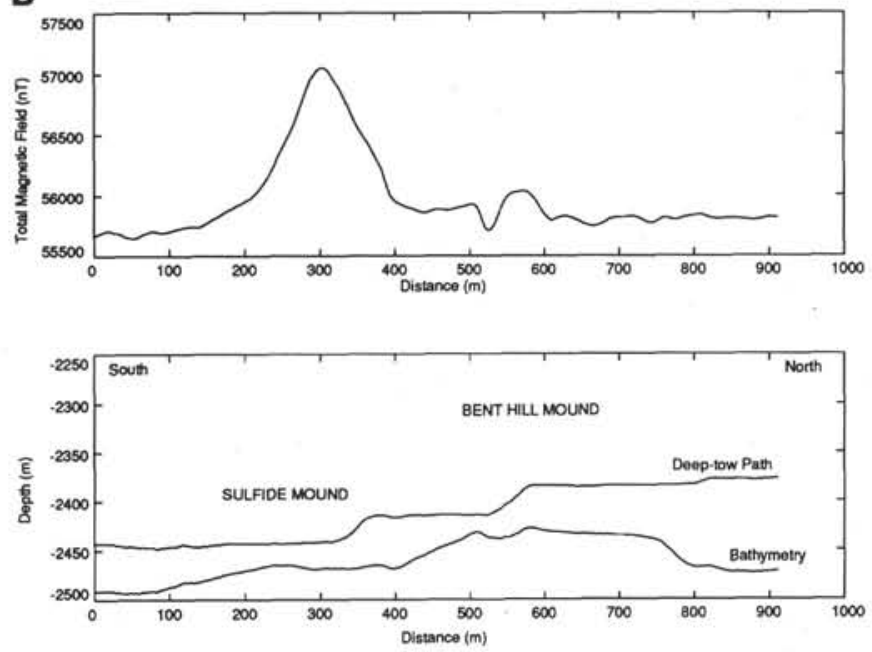

Figure 5 (continued).

with the active high-temperature vent site $300 \mathrm{~m}$ south of the main Bent Hill mound.

\section{SULFIDE MOUND MAGNETIC ANOMALY AT BENT HILL}

What information can the observed magnetic anomaly field over the Sulfide mound provide about the areal and depth extent of the mineralization? With respect to areal extent, the deep-tow and submersible tracks help constrain the magnetic anomaly high to a small zone no greater than $300 \mathrm{~m}$ in diameter with no evidence for significant strike extent that would indicate a dike (see Figs. 3 and 6). The ALVIN profile (Fig. 7) provides the best control on the width of the anomaly and suggests a magnetized body less than $60 \mathrm{~m}$ in a northsouth extent, which is consistent with the drilling results. The shape of the Sulfide mound magnetic anomaly may also be indicative of the type of source body and the direction of magnetization. The steeper north side of the magnetic anomaly with a small low (Fig. 7) indicates a small northward-dipping magnetization direction that is consistent with an induced anomaly at this latitude (i.e., magnetized in the same direction as the Earth's field, inclination $69^{\circ}$, declination $21^{\circ} \mathrm{W}$ ).

The observed anomaly can be modelled using the analytic solutions for a magnetized sphere or rod (Telford et al., 1976; Dobrin, 1976). Figure 8 shows that the observed ALVIN magnetic profile can be successfully modelled by a buried sphere or a buried rod of infinite length for various magnetizations. A sphere of magnetized material produces a magnetic field that is equivalent to the magnetic field of a dipole source located at the center of the sphere. The magnetic field of an infinitely long rod is equivalent to a monopole source when the rod is magnetized along its length and dips in the direction of the field $\left(69^{\circ}\right.$ at this latitude).

The analytic solutions for the rod and sphere allow estimates of the source body depth to be made based on the half-width of the observed anomaly. For example, the width of the magnetic anomaly over a buried sphere at half the peak anomaly amplitude is approximately equal to the depth to the center of the sphere (Telford et al., 1976). The observed magnetic anomaly in the submersible profile (Fig. 7) has a width of about $65 \mathrm{~m}$ at an altitude of $5 \mathrm{~m}$ above the seafloor, implying a source depth for a sphere of $60 \mathrm{mbsf}$. The maximum radius for the sphere is also $60 \mathrm{~m}$ because the sulfide body outcrops, suggesting a maximum depth extent of $120 \mathrm{mbsf}$. From the depth and radius of a spherical source body, a volume can be calculated so that a percentage of magnetite can be predicted using the observed amplitude of the anomaly and assuming a bulk susceptibility (Dobrin, 1976). Approximately $2.5 \%$ magnetite by volume is required to produce the $6000-n \mathrm{~T}$ 

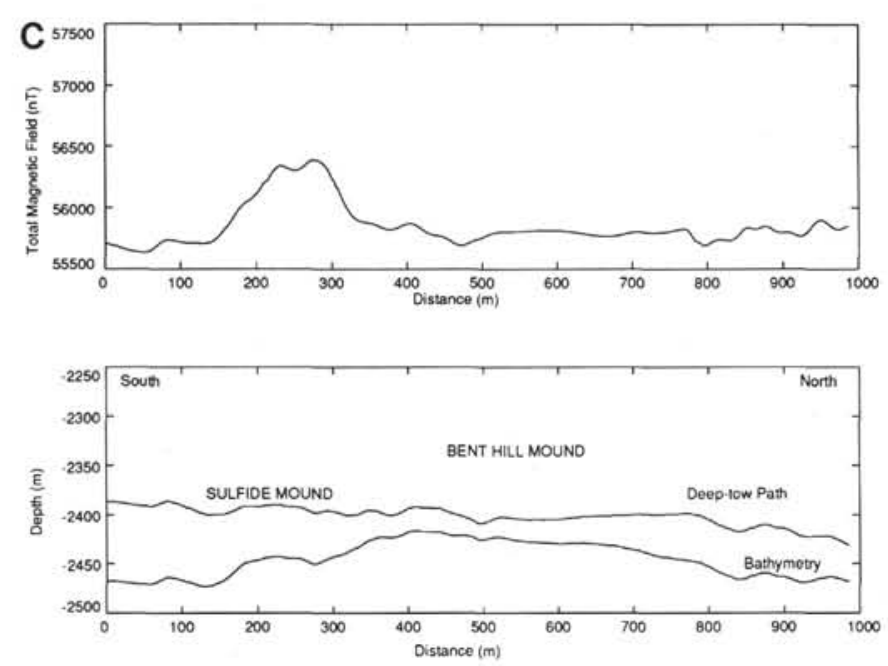

Figure 5 (continued).

anomaly measured by $A L V I N$ (where magnetite susceptibility is assumed to be $0.5 \times 4 \pi$ S.I. units). Alternatively, using a mean susceptibility of $0.13 \times 4 \pi$ S.I. from discrete sample measurements taken from Hole 856 (Körner, this volume), about $10 \%$ by volume is required to create the observed magnetic anomaly. This value is consistent with other measures of magnetite content (Körner, this volume) and the qualitative assessment of $10 \%-25 \%$ magnetite reported from core studies of Holes 856G and 856H (Shipboard Scientific Party, 1992). From the analytic solution for an infinitely long rod, the depth to the top of a buried rod is approximately equal to the anomaly half-width at half-peak amplitude. The magnetic anomaly half-width of the submarine profile is approximately $32 \mathrm{~m}$, implying a depth to the top of a buried rod of 27 mbsf.

Another approach is to look at the rate of fall-off in amplitude of the observed anomaly in comparison to the analytic signal. The magnetic field amplitude of a buried sphere or dipole falls off with distance by a factor of $1 / \mathrm{r}^{3}$, whereas the magnetic field amplitude of a buried rod or monopole falls off with distance by a factor of $1 / \mathrm{r}^{2}$. This difference in fall-off rate is shown in Figure 9, which shows a steeper fall-off rate for a sphere compared with a rod. The anomaly width measurement in the ALVIN profile at $5 \mathrm{~m}$ altitude is compared to the anomaly width measured at greater altitudes of 50 and $25 \mathrm{~m}$ in profiles DTM88-6 and DTM88-2, respectively (Fig. 9). The intersection of the line joining these two points with the abscissa is an estimate of the source body depth, approximately $30 \mathrm{~m}$ for the rod or $60 \mathrm{~m}$ for the sphere. The buried rod curve appears to be the closer fit to the observed data.

Finally, although the buried sphere and infinitely long buried rod models can provide some insight into the source body geometry, the actual mineralized zone probably falls somewhere in between (i.e., a pipe). The sphere model has a pronounced magnetic low on the north side of the anomaly compared to the buried rod model, which does not show any magnetic low (Fig. 8). The observed magnetic data shows a small low to the north, which would suggest that some intermediate model between a rod and sphere is a closer fit. If, instead of dipping, the buried rod were vertically oriented (i.e., pipelike) and magnetized in the direction of the Earth's field, a small magnetic low could be produced on the north side of the magnetic anomaly comparable to that observed. An estimate of the length of the pipe dimensions can be obtained from a dipole magnetic moment analysis (Tivey et al., 1993). The sphere model (Fig. 8) shows that the amplitude of the Sulfide mound anomaly is approximated by a sphere of radius 60 $\mathrm{m}$ with a magnetization of $8 \mathrm{~A} / \mathrm{m}$. The magnetic dipole moment is the product of the source volume and magnetization intensity, which for the Sulfide anomaly is approximately $7.2 \times 10^{6} \mathrm{~A} \mathrm{~m}^{2}$. If a pipe-like body is assumed, then given the maximum estimate of the pipe dia-

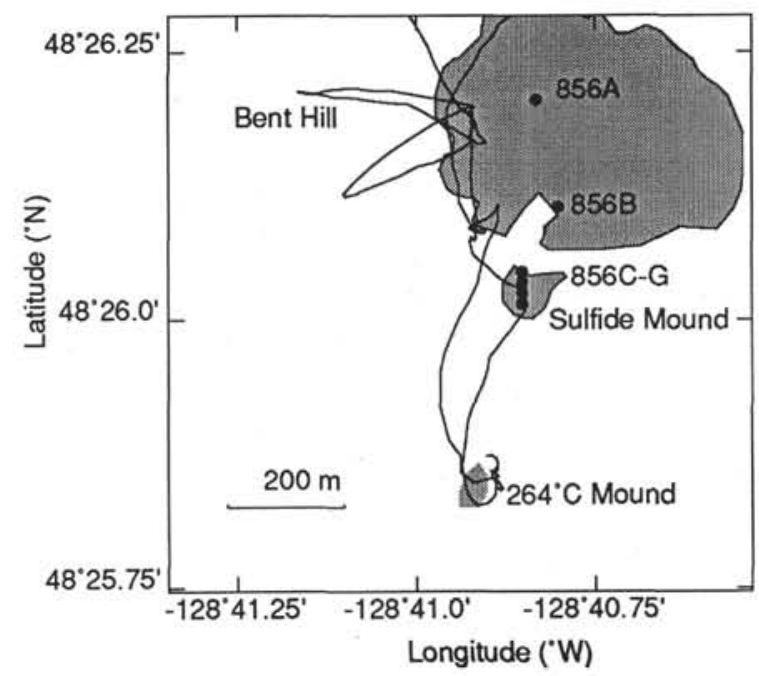

Figure 6. Map showing the ALVIN Dive 2253 trackline in the Bent Hill mound region. The main Bent Hill mound and Sulfide mound are shown shaded gray.
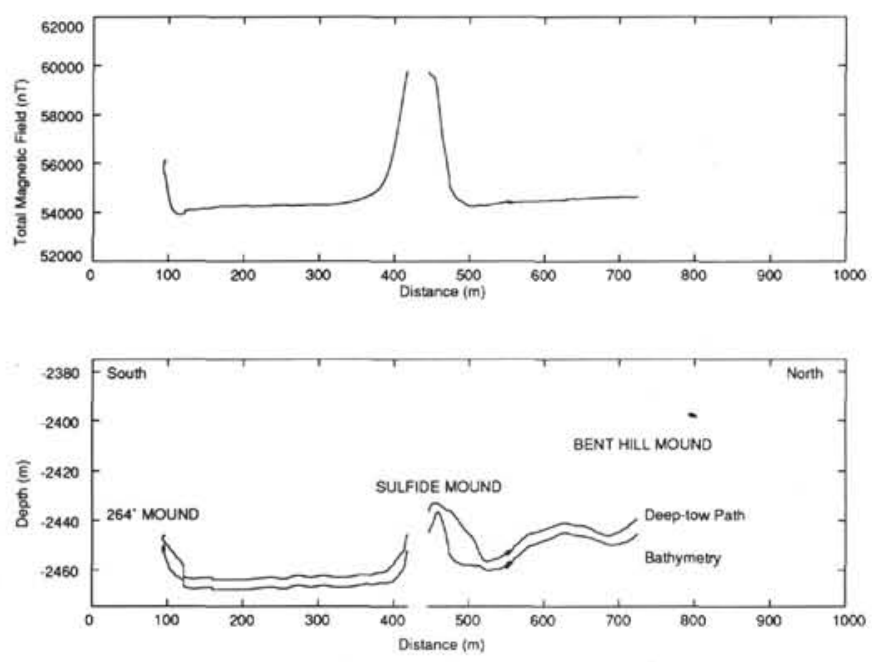

Figure 7. ALVIN magnetic profile 2253 showing the bathymetry and submersible path in the lower box and the observed total magnetic field in the upper box. This north-south profile crosses the Sulfide mound and southern portion of the main Bent Hill mound and shows the strong $6000 \mathrm{nT}, 100 \mathrm{~m}$ wavelength magnetic anomaly at the Sulfide mound. Note that there appears to be another magnetic high at the southern end of the profile at the location of the $264^{\circ} \mathrm{C}$ active vent site. The disruption in the magnetic field at the top of the Sulfide mound magnetic anomaly is due to $A L V I N$ sampling and a data gap.

meter of $60 \mathrm{~m}$, the length of a pipe-like body can be calculated for a particular magnetization. For example, if the pipe is magnetized to 10 $\mathrm{A} / \mathrm{m}$, it would have to be approximately $250 \mathrm{~m}$ long or only half as long if the magnetization is $20 \mathrm{~A} / \mathrm{m}$. The paleomagnetic results for the few sulfide samples that were reduced to stable components suggest a magnetization of $14 \mathrm{~A} / \mathrm{m}$ (Shipboard Scientific Party, 1992), which predicts a maximum pipe depth of $180 \mathrm{~m}$.

\section{CONCLUSIONS}

Near-bottom magnetic field surveys over two hydrothermal mound areas in the sedimented Middle Valley region of the northern Juan de Fuca Ridge detect highly magnetic bodies at depth, south of the main Bent Hill mound. A large positive 6000-nT magnetic anomaly is identified at the Sulfide mound, $100 \mathrm{~m}$ southwest of the main Bent Hill 
A

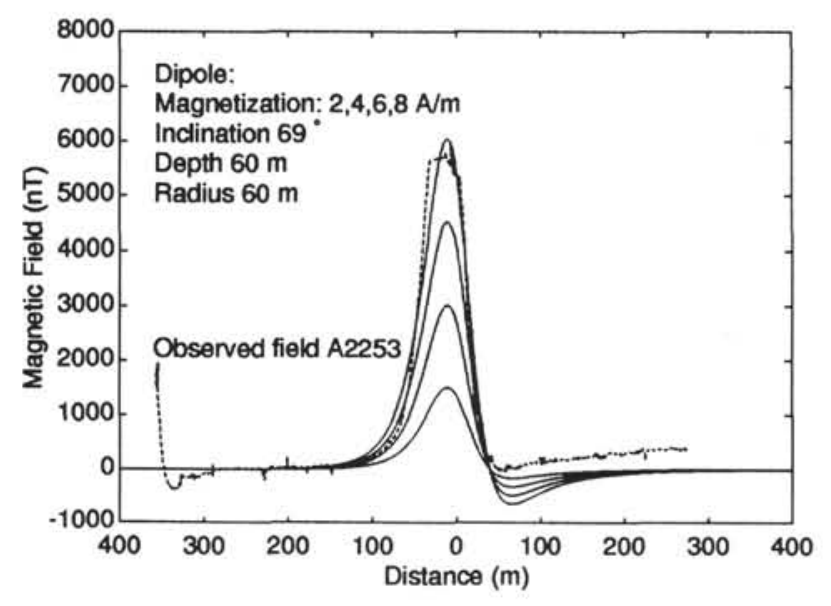

B

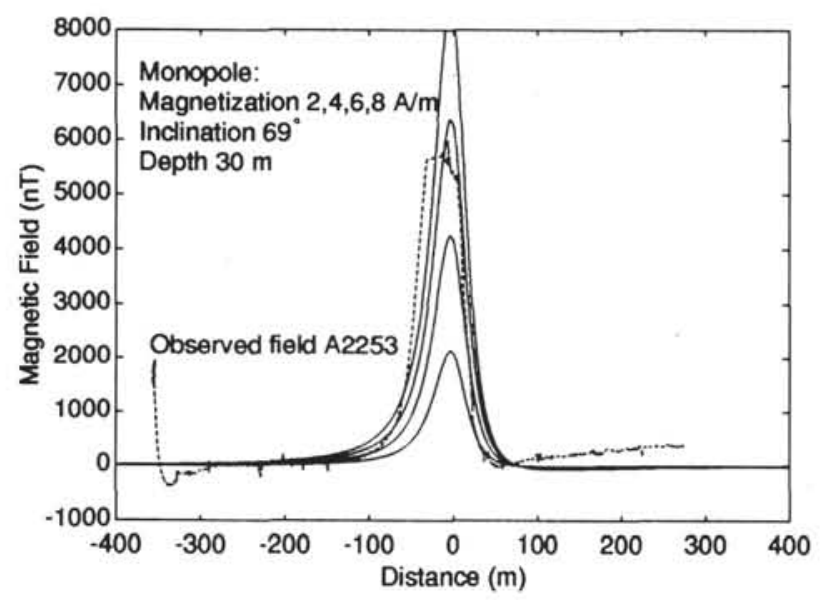

Figure 8. A. Forward model of a buried sphere (dipole) centered at $60 \mathrm{~m}$ depth for various magnetizations in comparison with the observed submarine profile (dotted line). B. Forward model of an infinitely long rod (monopole) dipping at $69^{\circ}$ along the Earth's field direction and buried at $30 \mathrm{~m}$ depth for various magnetizations in comparison with the observed submarine profile (dotted line).

mound at Site 856. A smaller anomaly is detected over the active $264^{\circ} \mathrm{C}$ vent site, $300 \mathrm{~m}$ south of Bent Hill mound. These magnetic anomalies arise from a combination of magnetic pyrrhotite and magnetite mineralization that makes up a significant proportion of the massive sulfide deposit. The Sulfide mound anomaly can be modelled by a buried magnetized sphere at depth 60 mbsf with a radius of $60 \mathrm{~m}$ and a magnetite content of $25 \%$ or a long rod buried at $30 \mathrm{~m}$ depth. In both cases, these models predict continued mineralization at depth to at least $120 \mathrm{mbsf}$. A more realistic pipe-like body, $60 \mathrm{~m}$ in diameter, magnetized to $14 \mathrm{~A} / \mathrm{m}$, would need to have a depth extent of $180 \mathrm{~m}$ to produce the observed anomaly amplitude. These results are consistent with the drilling results to date, which show a mineralized zone extending to a depth greater than 95 mbsf.

In contrast to Bent Hill, no magnetic anomalies are seen over the Dead Dog hydrothermal field, which suggests that no magnetic sulfide bodies are present at depth. This is consistent with the drilling results. The lack of any significant accumulation of massive sulfide deposits at Dead Dog vent field compared with Bent Hill could be due to a difference in age, but it is more likely that the hydrothermal regime is different between the two mound sites. The current hydrothermal discharge system does not appear to be the same system that formed the massive sulfide deposits of the Bent Hill mound area (Shipboard Scientific Party, 1992). Hydrothermal discharge at the

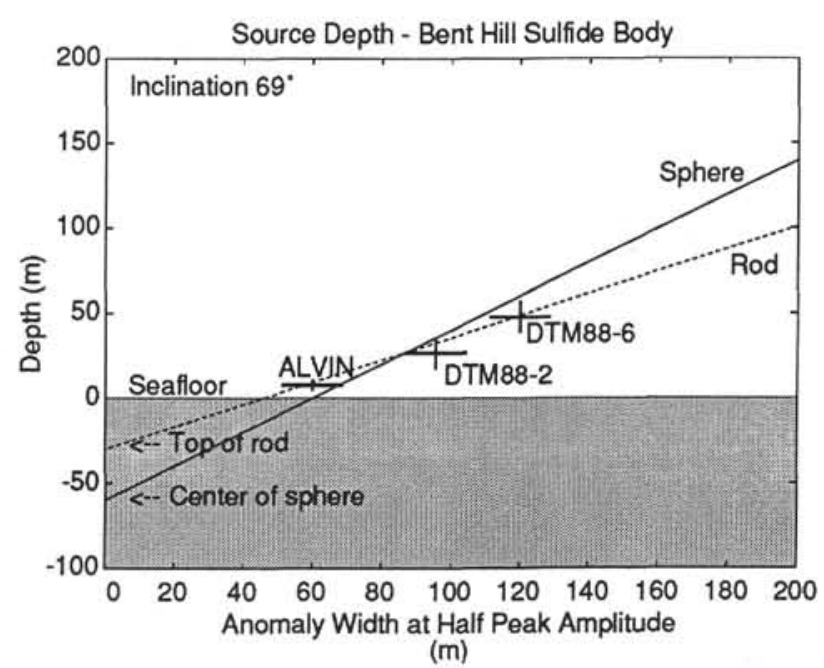

Figure 9. The relationship between the theoretical fall-off curves for a sphere (dipole) (solid line) and a rod (monopole) (dotted line) in comparison with the measured anomaly widths from deep-tow and ALVIN measurements. The observed data fit the buried rod model better than the sphere model.

Dead Dog mound area has not formed the deposits that are found at Bent Hill.

Although several holes intersected basaltic sills during Leg 139 , the low remanent magnetization and low stability of these rocks precludes them as magnetic source bodies. No magnetic anomalies could be attributed to basaltic sill units at depth.

Finally, this study shows that near-bottom magnetic surveys can be useful in delineating subsurface bodies, especially in the sedimentary environment, where the magnetic contrast between the host rock and mineralized body is high. This would not be the case in a barerock environment, such as at a mid-ocean ridge, where hydrothermal systems are more likely to produce a magnetic low rather than a magnetic high as a result of the pervasive alteration of the host rock (Tivey et al., 1993).

\section{ACKNOWLEDGMENTS}

I would like to thank Jim Franklin for providing ship time to carry out the deep-tow magnetic surveys and Paul Johnson for the use of the University of Washington Deep-tow Magnetometer system and for the use of the ALVIN Mesotech bathymetry data. Brian Halbert provided his usual excellent technical support in mobilization and demobilization of the deep-tow magnetometer system. I would also like to thank the crews of the CSS Tully, Atlantis II, and ALVIN Group for their hard work during these cruises. The manuscript was improved by reviews from several anonymous reviewers and by discussions with Hans Schouten. This work was supported by JOI/USSAC funds for site survey augmentation. Woods Hole Oceanographic Institution contribution number 8297 .

\section{REFERENCES $*$}

Davis, E.E., Goodfellow, W.D., Bornhold, B.D., Adshead, J., Blaise, B. Villinger, H., and Le Cheminant, G.M., 1987. Massive sulfides in a sedimented rift valley, northern Juan de Fuca Ridge. Earth Planet. Sci. Lett., 82:49-61.

Davis, E.E., and Villinger, H., 1992. Tectonic and thermal structure of the Middle Valley sedimented rift, northern Juan de Fuca Ridge. In Davis, E.E.,

\footnotetext{
Abbreviations for names of organizations and publications in ODP reference lists follow the style given in Chemical Abstracts Service Source Index (published by American Chemical Society).
} 
Mottl, M.J., Fisher, A.T., et al., Proc. ODP, Init. Repts., 139: College Station, TX (Ocean Drilling Program), 9-41.

Dobrin, M.B., 1976. Introduction to Geophysical Prospecting (3rd ed.): New York (McGraw Hill).

Franklin, J.M., Goodfellow, W.D., Blaise, B., Anglin, C.D., Harvey-Kelly, F.L., Macdonald, R., and Kappel, E., 1987. Geological map and distribution of sulfide deposits in Middle Valley, Northern Juan de Fuca Ridge. Eos, 68:1545.

Goodfellow, W.D., Jonasson, I.R., Blaise, B., Franklin, J.M., and Grapes, K., 1987. Nature of sulfide-rich mounds in sediment-filled Middle Valley, Northern Juan de Fuca Ridge. Eos, 68:1546.

Irving, E., 1970. The Mid-Atlantic Ridge at $45^{\circ} \mathrm{N}$. XIV. Oxidation and magnetic properties of basalt; review and discussion. Can. J. Earth Sci., 7:1528-1538.

Johnson, H.P., and Atwater, T., 1977. Magnetic study of basalts from the Mid-Atlantic Ridge, lat. $37^{\circ}$ N. Geol. Soc. Am. Bull., 88:637-647.

Johnson, H.P., and Holmes, M.L., 1989. Evolution in plate tectonics: a study of the Juan de Fuca Ridge. In Winterer, E.L., Hussong, D.L., and Decker, R.W. (Eds.), The Eastern Pacific Ocean and Hawaii. Geol. Soc. Am., Geol. of North Am. Ser., N:73-91.
Levi, S., and Riddihough, R., 1986. Why are marine magnetic anomalies suppressed over sedimented spreading centers? Geology, 14:651-654.

Press, W.H., Flannery, B.P., Teukolsky, S.A., and Vetterling, W.T., 1986. Numerical Recipes: the Art of Scientific Computing: Cambridge (Cambridge Univ. Press).

Shipboard Scientific Party, 1992. Davis, E.E., Mottl, M.J., Fisher, A.T., et al., Proc. ODP, Init. Repts., 139: College Station, TX (Ocean Drilling Program).

Telford, W.M., Geldart, L.P., Sheritt, R.E., and Keys, D.A., 1976. Applied Geophysics: Cambridge (Cambridge Univ. Press).

Tivey, M.A., and Johnson, H.P., 1989. High-resolution geophysical studies of oceanic hydrothermal systems. CRC Crit. Rev. Aquat. Sci., 1:473-496.

Tivey, M.A., Rona, P.A., and Schouten, H., 1993. Reduced crustal magnetization beneath the active sulfide mound, TAG Hydrothermal Field, MidAtlantic Ridge $26^{\circ}$ N. Earth Planet. Sci. Lett., 115:101-115.

Date of initial receipt: 12 November 1992
Date of acceptance: 29 April 1993
Ms 139SR-205 